\title{
KORUPSI, KOLUSI DAN NEPOTISME PERSPEKTIF HADITS
}

\author{
Teguh Luhuringbudi \\ Universitas Islam Negeri Syarif Hidayatullah, Jakarta, Indonesia \\ sampaiteguh@gmail.com
}

Achmad Yani

Kantor Wilayah Kementrian Agama, Kabupaten Buleleng, Bali, Indonesia

achmadyani.yani@yahoo.co.id

\begin{abstract}
This study concludes that the rise of corruption, collusion, and nepotism in the time of the Prophet Muhammad comes from a variety of special terms and is contained in hadith. These emerging terms affect the different usage associations of each term. The method used in this research is analytical and descriptive method. This study uses two approaches. The first approach used in the research is the 'ilm al-Hadith approach. This approach is used to measure hadith-hadith relating to corruption, collusion and nepotism in terms of quality of matan and sanad; and its asbāb al-Wurūd. The second approach is the linguistic approach. This approach is enabled to explore the rationality of corruption, collusion, and nepotism through tradition, systematics, and language tendencies in producing an understanding. This research has several objectives. Firstly, to authenticate corruption, collusion, and nepotism as disciplinary and inconsistent attitudes that can be present in human beings without being limited by the dimension of time and space. Secondly, to verify and measure the existence of cases of corruption, collusion, and nepotism in the time of Mu'ammad ibn 'Abdillāh by analyzing the matan al-Hadith, Sharh al-Hadìth, and asbāb al-Wurūd. Thirdly, inventory the terms of corruption, collusion, and nepotism in hadith and map their usage.
\end{abstract}

Keywords: Corruption, Collusion, Nepotism, and Hadith

Abstrak. Penelitian ini menyimpukan bahwa maraknya karupsi, kolusi, dan nepotisme pada masa nabi Muhammad hadir dari istilah khusus yang beragam dan terdapat dalam hadith. Istilah-istilah yang muncul tersebut berdampak pada asosiasi penggunaan yang berbeda dari masing-masing istilahnya. Metode yang digunakan dalam penelitian ini adalah metode analitis dan deskriptif. Penelitian ini menggunakan dua pendekatan. Pendekatan pertama yang digunakan dalam penelitian adalah pendekatan ilm alHadith. Pendekatan ini difungsikan untuk menakar hadìth-hadìth yang berkaitan dengan korupsi, kolusi, dan nepotisme secara kualitas matan dan sanadnya; dan asbāb al-Wurūd nya. Pendekatan kedua adalah pendekatan kebahasaan. Pendekatan ini difungsikan untuk menelusuri rasionalitas terjadinya korupsi, kolusi, dan nepotisme melalui tradisi, sistematika, dan kecenderungan kebahasaan dalam memproduksi suatu pemahaman. Penelitian ini memiliki beberapa tujuan. Pertama, mengobjektifikasi korupsi, kolusi, dan nepotisme sebagai sikap indisipliner dan inkonsisten yang dapat hadir dalam diri manusia tanpa dibatasi dimensi waktu dan ruang. Kedua, memastikan dan mengukur keberadaan kasus korupsi, kolusi, dan nepotisme pada masa Muhammad ibn 'Abdillāh dengan menganalisis matan al-Hadïth, Sharh al-Hadīth, dan asbāb al-Wurūd. Ketiga, menginventarisir istilah-istilah korupsi, kolusi, dan nepotisme dalam hadīth dan memetakan penggunaannya.

Kata Kunci: Korupsi, Kolusi, Nepotisme, dan Hadīth 


\section{Pendahuluan}

Muhammad ibn 'Abdillāh merupakan sosok yang menjadi teladan dengan kebulatan perangai dari berbagai sudut pandang. Pandangan yang menyatakan bahwa Muhammad ibn Abdillah sebagai sosok yang sempurna seringkali tidak dapat lepas dari intervensi subyektif.

Subyektifitas tersebut didasarkan pada norma, ikatan ideologis, pemahaman konservatif, dan keterlibatan dogma. Pandangan lain menyatakan kebulatan perangai yang berkonotasi positif didasarkan pada budaya ilmiah yang pada akhirnya menghasilkan negative frame maupun positive frame pada diri Muhammad ibn Abdillah.

Hal tersebut didasarkan pada upaya merespon suatu thesa yang menyatakan bahwa Muhammad ibn 'Abdillāh sebagai sosok yang berperangai baik tanpa atau minim nilai indisipliner-inkonsistensi. Respon yang diterapkan berupa budaya ilmiah dan tradisi tulis untuk membuktikan sejauh mana tingkat perangai baik yang ada pada diri Muhammad ibn Abdillāh.

Kedua pandangan tersebut bermuara pada upaya menghadirkan antithesa atau pertanyaan kritis berupa sejauh mana integritas moral Muhammad ibn 'Abdillāh sebagai public figure dan kontekstualisasinya?

Etika Nabi Muhammad SAW dan dekadensi moral umat Islam merupakan diskursus yang tidak kunjung selesai dan selalu melibatkan subyektifitas dari setiap variabel pengukurannya. Variabel pengukuran berupa disiplin keilmuan (Islamic Studies, Dirāsāt Islāmiyyah) yang sejatinya memiliki nuansa obyektif dan bebas nilai digunakan untuk melegitimasi suatu sikap ideologisdogmatis-subyektif sebelum penelitian (terkait) berhasil memproduksi hasil penelitian.
Upaya

mengkomparasikan

diskursus waktu atau tempat dalam tema atau kasus tertentu tidak lebih dari upaya kesewenang-wenangan untuk memberi sentimen positif pada waktu atau tempat tertentu dan sentimen negatif terhadap waktu atau tempat lain.

Objektifikasi suatu moralitas harus dilakukan dengan menetralkan suatu tema atau kasus dengan menyampaikan pengetahuan bahwa setiap dimensi waktu dan tempat memiliki dinamika tersendiri dan tidak dapat disamakan dengan yang lain.

Dinamika etika Muhammad ibn 'Abdillāh sebagai public figure yang dibandingkan dengan dekadensi moral umat Islam perlu dilakukan objektifikasi. Beragam kepribadian dan perilaku setiap manusia merupakan unifikasi yang rumit untuk diidentifikasi, apalagi diteliti secara mendalam.

Upaya pengukuran etika dan moral umat Islam di dimensi waktu dan tempat yang berbeda perlu dikhususkan pada tema, pengambilan data, disiplin keilmuan, dan tujuan tertentu sehingga diharapkan dapat menghasilkan wawasan yang mendalam, deeply added insight. Hal ini juga berguna dalam melacak dan memastikan dinamika moralitas pada masa Nabi Muhammad ibn 'Abdillāh.

Penelusuran etika Muhammad SAW dan moralitas masyarakat di zamannya perlu ditilik pada tema korupsi, kolusi, dan nepotisme. Hal ini tidak hanya didasarkan pada stigma korupsi sebagai extraordinary crime, namun juga keberadaan kolusi dan nepotisme yang berdampak pada dimensi ketata-negaraan, sosial, keadilan, kemanusiaan, dan hak asasi manusia.

Pelacakan sejarah korupsi, kolusi, dan nepotisme di masa Nabi SAW menjadi pertimbangan tersendiri dalam mengukuhkan teori sejarah dari ketiga tema tersebut. Pelacakan tersebut 
menjadi stimulasi dalam memicu penelitian-penelitian lanjutan yang membahas penanganan korupsi, kolusi, dan nepotisme.

Pemahaman mendasar tentang ketiga tema tersebut didasarkan pada keterbatasan dalam mengendalikan id, ego, dan superego sekaligus fitrah manusia untuk mengaktualisasikan kebahagiaan paripurna. Perolehan kebahagiaan sempurna sebagai fitrah manusia secara alami akan membenarkan korupsi, kolusi, dan nepotisme.

Hal ini berarti bahwa ketiga tema tersebut tidak hanya terjadi di Indonesia saja atau di zaman reformasi pemerintahan Indonesia saja, namun jauh pada masa sebelumnya manusia telah mengalami bahkan melestarikan korupsi, kolusi, dan nepotisme.

\section{Pondasi Primordial: Definisi, Historisitas, Normativitas, dan Dinamika Korupsi, Kolusi, dan Nepotisme}

Definisi korupsi, kolusi, dan nepotisme dapat dilihat dari sudut pandang hukum dalam konteks keIndonesia-an. Korupsi adalah penyalahgunaan amanah untuk kepentingan pribadi. ${ }^{1}$

Produk hukum mendefinisikan kolusi sebagai pemufakatan atau kerjasama secara melawan hukum antar-Penyelenggara Negara atau antar

1 Syamsul Anwar, Fikih Antikorupsi: Perspektif Ulama Muhammadiyah Majelis Tarjih dan Tajdid PP. Muhammadiyah (Jakarta: Pusat Studi Agama dan Peradaban, 2006), 10. Teguh Luhuringbudi, Analisa Pengaruh al-Qawāid alUșūliyyah dan al-Fiqhiyyah terhadap Perbedaan Pendapat dalam Fiqih: Kasus Hukuman untuk Tindak Pidana Korupsi, Makalah Matakuliah Islamic Law (Jakarta: Sekolah Pascasarjana Universitas Islam Negeri Syarif Hidayatullah, 2016), 1.

2 Kolusi dalam aspek perdagangan didefinisikan sebagai hubungan antara penawar (bidder) yang membatasi persaingan dan merugikan pembeli publik. 24 .
Penyelenggara Negara dan pihak lain yang merugikan orang lain, masyarakat, dan atau negara. ${ }^{2}$ Nepotisme adalah setiap perbuatan Penyelenggara Negara secara melawan hukum yang menguntungkan kepentingan keluarganya dan atau kroninya di atas kepentingan masyarakat, bangsa, dan negara. $^{3}$

Perbedaan pendapat muncul terkait entitas korupsi, kolusi, dan nepotisme. Pendapat yang memposisikan ketiganya sebagai satu kesatuan dapat dilihat dari Undangundang Republik Indonesia Nomor 46 tahun 2009 yang berbunyi, "tindak pidana yang secara tegas dalam undangundang lain ditentukan sebagai tindak pidana korupsi." 4

Pendapat yang tidak secara inklusif menyebutkan nepotisme dan kolusi sebagai satu entitas dengan korupsi tersebut dijelaskan dalam ayat 2 pasal 5 UU RI Nomor 20 Tahun 2001 yang berbunyi, "Yang dimaksud penyelenggara negara dalam Pasal ini adalah penyelenggara negara sebagaimana dimaksud dalam Pasal 2 Undang-undang Nomor 28 Tahun 1999 tentang Penyelenggara Negara yang Bersih dan Bebas dari Korupsi, Kolusi, dan Nepotisme. Pengertian penyelenggara negara tersebut berlaku pula untuk pasal-pasal berikutnya dalam Undang-undang ini."5

\footnotetext{
3 Undang-undang Republik Indonesia Nomor 28 Tahun 1999 tentang Penyelenggaraan Negara yang Bersih dan Bebas dari Korupsi, Kolusi, dan Nepotisme, Bab I Ketentuan Umum, Pasal 1, Ayat 3, 4, dan 5.

4 Undang-undang Republik Indonesia Nomor 46 Tahun 2009 tentang Pengadilan Tindak Pidana Korupsi, Bab III (Kewenangan), Pasal 6, Butir C.

${ }^{5}$ Penjelasan atas Undang-undang Republik Indonesia Nomor 20 Tahun 2001 tentang Perubahan atas Undang-undang Nomor 31 Tahun 1999 tentang Pemberantasan Tindak Pidana Korupsi, Pasal 5 Ayat 2.
} 
Korupsi, kolusi, dan nepotisme merupakan tindakan indisipliner yang terjadi sejak lama, baik dalam konteks ke-Indonesia-an maupun sejarah di masa Muhammad ibn 'Abdillāh.

Luhuringbudi mencontohkan ketiga tindakan tersebut dalam konteks ke-Indonesia-an dengan pemlesetan singkatan "Vereenigde Oost-Indische Compagnie" yang berarti "Persekutuan Perusahaan Hindia Timur" menjadi redaksi "Vergaan Onder Corruptie" yang berarti "Bangkrut Karena Korupsi" pada tahun 1602.6

Ketiga tindakan tersebut juga terjadi di masa Muhammad ibn 'Abdillāh yang berdampak pada produk hukum berupa kehalalan ganimah (harta rampasan perang). Hal ini diperjelas dengan kutipan Hadis berikut:

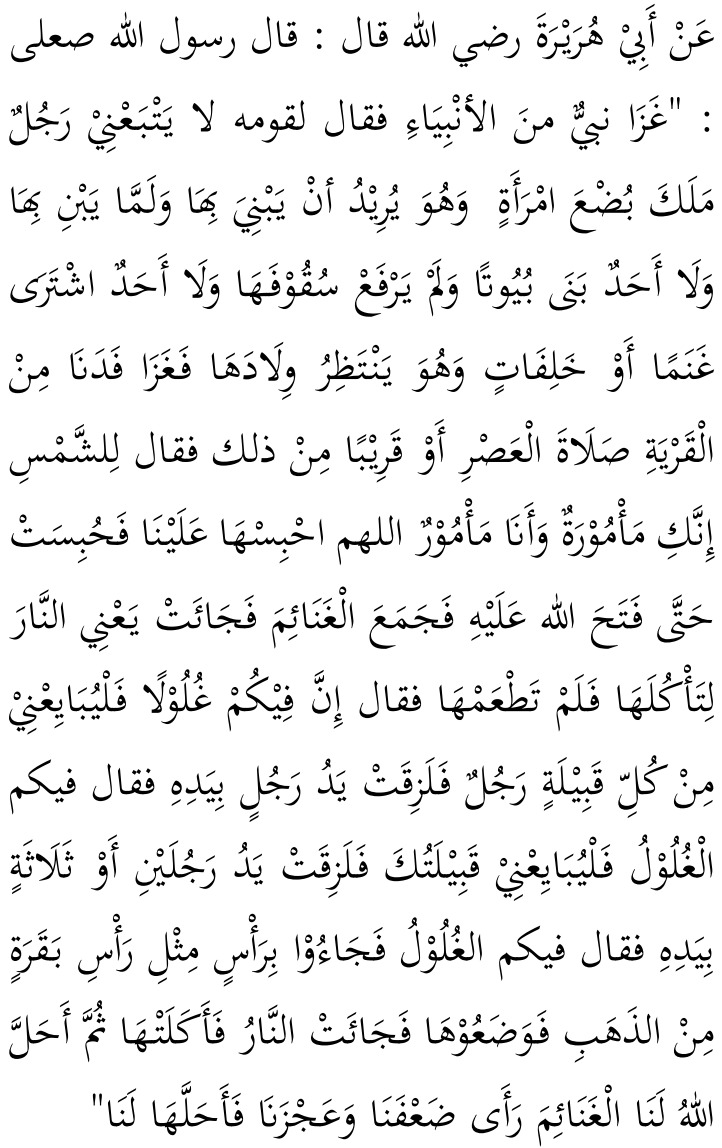

${ }^{6}$ Teguh Luhuringbudi, Analisa Pengaruh al-Qawāid al-Ușūliyyah dan al-Fiqhiyyah terhadap Perbedaan Pendapat dalam Fiqih: Kasus Hukuman untuk Tindak Pidana Korupsi,
Peristiwa perang di masa Muhammad merupakan peristiwa sejarah yang menelurkan empat kasus sekaligus. Kasus pertama adalah kasus kolusi. Hal ini ditunjukkan dengan adanya persekongkolan dalam menyembunyikan harta sebagaimana

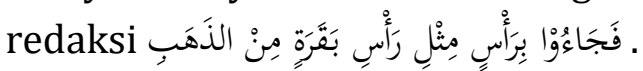

Tindakan penyembunyian harta yang dilakukan oleh pasukan Muhammad ibn 'Abdillāh merupakan kerjasama dan pemufakatan jahat dalam melawan hukum (berupa instruksi Muhammad untuk mengumpulkan semua harta rampasan perang) yang merugikan rasa keadilan sesama prajurit.

Pembuktian persekongkolan sebagai inti dari definisi kolusi yang bermakna lebih dari satu subjek atau pihak dibuktikan dengan redaksi فَجَاُوُوا yang mengandung domìr-pronoun yang jama' atau plural. Hal ini dapat mengakibatkan kesenjangan dan perasaan iri bagi prajurit yang saling bekerjasama dalam perang namun tidak mendapatkan kompensasi atau apresiasi setelah perang sedangkan pihak atau prajurit mendapatkan kompensasi atau apresiasi.

Kasus kedua dari hadis tersebut adalah kasus korupsi. Variabel penyalahgunaan amanah dapat dilihat dari kemunculan instruksi sebagai basis normatif dan pengingkaran sebagai basis inkonsisten.

Basis normatif hadith tersebut dapat terlihat dari فَجَمَعَ الْغَنَائمَ Instruksi normatif Muhammad tidak sepenuhnya mendapatkan jawaban positif yang فَجَائَتْ يَعْنِي dibuktikan dengan fenomena

Makalah Matakuliah Islamic Law (Jakarta: Sekolah Pascasarjana Universitas Islam Negeri Syarif Hidayatullah, 2016), 1. 


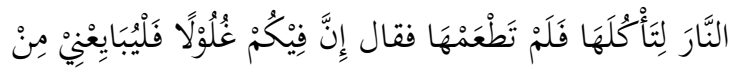

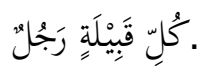

Kutipan tersebut merupakan upaya dalam memastikan sejauh mana instruksi atau hukum berjalan di grass root. Hal ini membuahkan hasil karena adanya penemuan penggelapan dengan

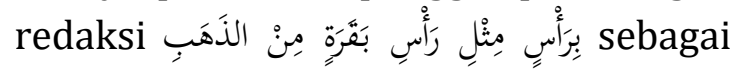
barang temuan. Terminologi al-Ghulūl dalam Hadis ini dapat dikategorikan sebagai korupsi berdasarkan definisi yang diutarakan oleh Muhammad Nāșir. ${ }^{7}$

Kasus ketiga adalah nepotisme. Hadis tersebut memberikan keterangan bahwa perbuatan melawan hukum dengan tidak mengumpulkan seluruh harta rampasan perang (ghanimah) merupakan suatu sikap indisipliner.

Perlawanan hukum ini dilakukan sebanyak tiga kali. Pertama ketika Nabi mengumpulkan harta rampasan perang merupakan suatu instruksi (فَجَمَعَ الْغَنَائمَ) agar seluruh prajurit turut melakukan hal yang sama walaupun hasil akhir menyatakan adanya ketidakpatuhan dan penggelapan.

Kedua, tidak adanya perasaan bersalah disertai pengakuan perbuatan indisipliner (sebagai bentuk perlawanan hukum) saat Nabi mengatakan ada indikasi gulūl hingga keadaan demikian menuntut adanya Pakta Integritas فقال إنَّ

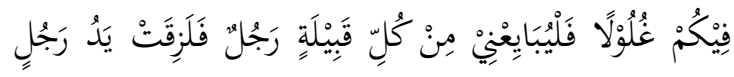
. بيَدِدِ.

7 Nāșir mendefinisikn al-Ghulūl adalah seorang yang mengambil harta rampasan perang secara diam-diam sedikit atau banyak dan tidak menyetorkannya kepada komandan perang untuk dibagi rata. Al-Shaikh Muhammad Nāṣir al-Dīn ibn al-Ḥāj Nūh al-Albāni, Șahīh alTarghīb wa al-Tarhīb, Juz 2: 30.

8 Teguh Luhuringbudi, Analisa Pengaruh al-Qawāid al-Ușūliyyah dan al-Fiqhiyyah
Ketiga, Pakta integritas tersebut memunculkan pernyataan dari Muhammad ibn 'Abdillah dalam mengukuhkan adanya tindakan perlawanan hukum dan tidak adanya satu pihak pun yang mengakui atau minimal memberi kesaksian terkait tindakan indisipliner gulūl yang terjadi. Hal ini dibuktikan dengan redaksi فقال

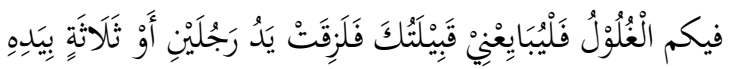
فقال فيكم الغُلْولُ

Tindakan indisipliner dengan tidak mengakui adanya gulūl (korupsi) merupakan fenomena ketidakstabilan sosial (social pathology) yang menurut Haller dan Shore disebabkan karena kurang maksimalnya kegunaan ilmu dan ranah sosial (social discipline) yang menggerogoti kehidupan sosial. ${ }^{8}$

Persekongkolan dalam melawan hukum untuk kepentingan keluarga dan kroni dibuktikan dengan adanya keterlibatan lebih dari satu pelaku dalam bentuk redaksi verbal فَجَاءُوا sebagai representasi dalam memahami fenomena nepotisme.

Kasus keempat adalah historisitas kehalalan ghanimah. Integritas dan dedikasi umat Islam terhadap instruksi pimpinan, Muhammad SAW yang tidak dapat dipertanggungjawabkan menghadirkan penilaian terhadap fenomena manusia dalam konteks hadis tersebut.

Hal ini menjadi pertimbangan Muhammad SAW dan Allah SWT dalam mengapresiasi lemahnya integritas dan dedikasi umat Islam dalam merawat budaya disiplin untuk menstimulasi

terhadap Perbedaan Pendapat dalam Fiqih: Kasus Hukuman untuk Tindak Pidana Korupsi, Makalah Matakuliah Islamic Law (Jakarta: Sekolah Pascasarjana Universitas Islam Negeri Syarif Hidayatullah, 2016), 1. Dieter Haller dan Cris Shore (Ed), Corruption: Anthropological Perspective (London: Pluto Press, 2005), 4. 
sistem dan birokrasi yang terarahterukur, good governance. Kasus korupsi, kolusi, dan nepotisme yang terjadi di saat perang tersebut melahirkan produk hukum berupa kehalalan ghanimah.

Korupsi muncul bukan tanpa sebab. Treisman membagi penyebab korupsi menjadi lima sebab. Pertama, income kompetitif berbanding terbalik dengan kinerja. Kedua, intervensi pemerintah terhadap pasar terlalu tinggi. Ketiga, perlakuan sama terhadap beragam komoditas atau produk oleh pemerintah. Keempat, undang-undang atau peraturan yang rumit dan tidak transparan. ${ }^{9}$ Sundell berpendapat bahwa korupsi lahir karena tidak adanya upaya memprofesi ${ }^{10}$ onalkan birokrasi untuk melindungi dari pengaruh politik.

Suksesi tindakan sekaligus pelestarian kolusi terjadi karena beberapa faktor atau penyebab. Pertama, adanya kontrak atau pengadaan publik dengan sistem birokrasi dan administrasi yang lemah sehingga berpotensi melahirkan budaya persaingan yang tidak sehat. ${ }^{11}$

Kedua, pengadaan publik yang lebih khusus (terutama pengadaan barang) membuat prosesnya menjadi lebih khusus pula sehingga rentan terhadap praktik anti persaingan. Peraturan dan persyaratan yang menuntut proses yang lebih detil dan

9 Boris Begovic, Corruption: Concepts, Types, Causes, and Consequences (Center for International Private Enterprise Economic Reform Feature Service, 2005), 1-7. Daniel Treisman, "The Causes of Corruption: A Crossnational Study," Journal of Public Economics, 76 (2000): 399-457.

10 Anders Sundell, Nepotism and Meritocracy, QoG Working Paper Series (Gothenburg: The Quality of Government Institute, 2014), 4.

11 The OECD Global Forum on Competition, Collusion and Corruption in Public Procurement 2010: 9-10.

12 Hal ini berdampak pada upaya pelemahan demokrasi, menghambat tata berlebihan sehingga lebih mudah diprediksi dan memunculkan pelung kolusi. ${ }^{12}$ Ketiga, tidak adanya upaya pencegahan berupa penyelenggaraan sistem dan transaksi yang transparan.

Sebab-sebab

kemunculan

nepotisme dapat ditilik dari beberapa pendapat. Pendapat pertama muncul dari Sundell yang menyatakan bahwa nepotisme disebabkan empat hal.

Pertama, pengaruh politik yang dibuktikan dengan tidak adanya reformasi (sebagai suatu prinsip kenegaraan) sehingga profesionalitas birokrasi menjadi dipertanyakan. ${ }^{13}$ Prinsip yang dimaksud adalah promosi dan transformasi posisi tanpa biaya administratif dengan tuntutan adanya kreteria objektif yang salah satunya berupa persyaratan pendidikan.

Kedua, senioritas dan tidak adanya meritokrasi. Ketiga, adanya unsur kekeluargaan dalam suatu pekerjaan, tugas, atau tanggungjawab. ${ }^{14}$ Keempat, aristokrasi memiliki peluang dalam mengakses pendidikan yang lebih baik dan pada akhirnya menjamin keberadaan posisi politis dan karir tertentu. $^{15}$ Pendapat-pendapat yang menjabarkan sebab-sebab nepotisme tersebut memiliki dampak pada tidak berjalannya birokrasi yang professional.

Identifikasi praktik korupsi dapat dilihat dari beberapa unsur. Pertama, penyalahgunaan posisi publik untuk

pemerintahan yang sehat, dan menghambat investasi dan pembangunan ekonomi. The OECD Global Forum on Competition, Collusion and Corruption in Public Procurement 2010: 10.

13 Anders Sundell, Nepotism and Meritocracy, QoG Working Paper Series (Gothenburg: The Quality of Government Institute, 2014), 10.

14 Anders Sundell, Nepotism and Meritocracy, QoG Working Paper Series (Gothenburg: The Quality of Government Institute, 2014), 12-13.

15 Anders Sundell, Nepotism and Meritocracy, QoG Working Paper Series (Gothenburg: The Quality of Government Institute, 2014), 20. 
keuntungan finansial di bidang monopoli dalam berbagai pelayanan infrastruktur.

Kedua, memperoleh tender dengan cara yang tidak sah bagi perusahaan yang mimiliki hubungan dengan orang-orang di posisi publik. Ketiga, penunjukan individu atas dasar nepotisme.

Keempat, memfasilitasi perizinan dan pemotongan pajak untuk individu yang tidak memenuhi syarat berdasarkan hubungan pribadi. Kelima, penyalahgunaan barang publik untuk partai politik atau penggunaan pribadi. ${ }^{16}$

Pembatasan kajian penelitian ini didasarkan pada dua hal. Pertama, pembatasan berdasarkan tema besar dilakukan dengan memfokuskan pada wacana korupsi, kolusi, dan nepotisme. Kedua, pembatasan berdasarkan waktu adalah tinjauan hadis-hadis korupsi, kolusi, dan nepotisme yang mengindikasikan adanya ketiga tindakan indisipliner di masa nabi; dan konteks ke-Indonesia-an.

Kedua pembatasan ini untuk ditujukan untuk melihat kadar degradasi moral pada masa nabi dan pada masa reformasi di Indonesia. Ketiga, Hadis yang digunakan dalam penelitian ini adalah gulul, rishwah, suht, bai'āt al-Imām li dunya, dan jaur al-Qādì aw al-Imām.

Pembatasan masalah tersebut di atas merupakan dasar penelitian yang ditujukan untuk melakukan

${ }^{16}$ Azmi Shuabi, Elements of Corruption in th eMiddle East and North Africa: The Palestinian Case, disampaikan pada 9th International AntiCorruption Conference (IACC), 10-15 October, 1999, Durban, South Africa, 2.

17 Nur Achmad, PENCEGAHAN KORUPSI DALAM PERSPEKTIF HADIS Studi Hadis Korupsi dalam Kutub al-Sittah (Jakarta: Sekolah Pascasarjana UIN Syarif Hidayatullah, 2007), 103-128. Lihat dalam Tabel : Daftar Inventaris Hadis Korupsi.

18 Muslim, Sahīh, Kitāb al-Tahārah, Bāb Wujūd al-Ṭahārah li al-Ṣalāh, no. 224. Abū pengembangan studi hadis. Achmad berhasil menginventarisir hadis tentang korupsi yang dibagi menjadi tiga hadis gulul secara umum, empat belas hadis gulūl al-ganimah, sembilan hadis gulūl al-sadaqah dan hadiyyah al-'ummal, tiga hadis risywah, dua hadis suht, satu hadis bai'at al-imam li al-dunya, lima hadis jaur al-qadi aw al-imam. ${ }^{17}$

Iklim monoton yang dihadirkan Achmad dalam studi Hadisnya difokuskan pada tema besar korupsi semata. Penulis berusaha mengembangkan Hadis gulul, rishwah, suht, bai'àt al-Imām li dunya, dan jaur alQādī aw al-Imām pada pemetaan tema korupsi, kolusi, dan nepotisme. .

\section{The Facts of the Case}

\begin{tabular}{|c|c|c|c|}
\hline No & $\begin{array}{c}\text { Kategori } \\
\text { Hadīs }\end{array}$ & Hadis & $\begin{array}{c}\text { Nomor } \\
\text { Hadiss }\end{array}$ \\
\hline 1 & GulūI & 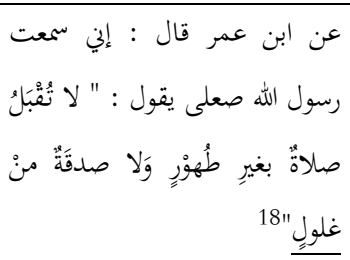 & G 1 \\
\hline 2 & & 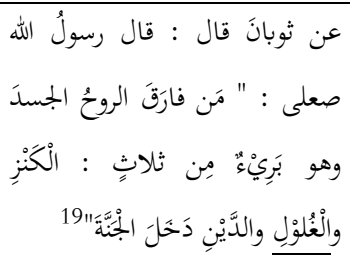 & G 2 \\
\hline 3 & & 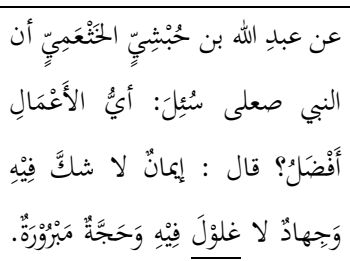 & G 3 \\
\hline
\end{tabular}

Dāwūd, Sunan, Kitāb al-Ṭahārah, Bāb Farḍi alWuḍū', no. 59, juz 1, h.36. Tirmiẓ̂̄, Sunan, Kitāb al-Ṭahārah, Bāb Mā Jā'a Lā Tuqbalu al-Ṣalāt bi Gairi Tahūr, no. 1, h. 9. Nasā'̄i, Sunan, Kitāb alTahārah, Bāb Farḍ al-Wuḍū', no 139, h. 31. Ibn Mājah, Sunan, Kitāb al-Ṭahārah, Bāb Lā Tuqbalu al-Ṣalāt bi Gairi Ṭahūr, no. 271, 272, 273, dan 274 , h. 57

19 Tirmizī, Sunan, Kitāb al-Sair, Bāb Mā Jā'a fi al-Ghulūl, No. 1573, h. 403. Ibn Mājah, Sunan, Kitāb al-Ṣadāqāt , Bāb al-Tashdīd fĩ al-Dain, No. 2412, h. 386. 


\begin{tabular}{|c|c|c|c|}
\hline & & 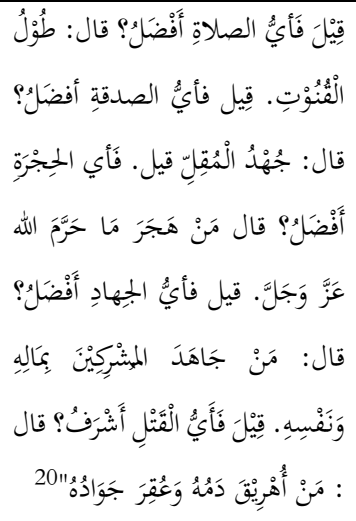 & \\
\hline 4 & Rishwah & 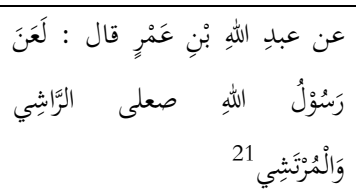 & R 1 \\
\hline 5 & & 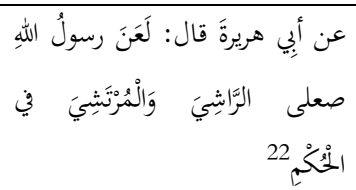 & R 2 \\
\hline 6 & & 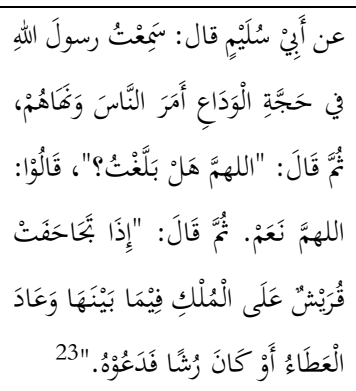 & R 3 \\
\hline 7 & Suḥt & 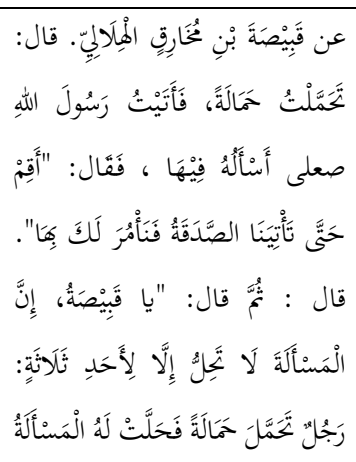 & S 1 \\
\hline
\end{tabular}

20 Tirmiẓ̄, Kitāb al-Ṭahārah, Bāb Mā Jā'a fi al-Gulūl, no. 1573, h. 403. Ibn Mājah, Sunan, Kitāb al-Ṣadāqāt, Bāb al-Tasydīd fĩ al-Daīn, no. 2412, h, 386.

21 Abū Dāwūd, Sunan, Kitāb al-Aqdiyah, Bāb fĩ Karāhiyati al-Rishwah, no. 3580, Juz. 3, h. 291. Tirmiẓī, Sunan, Kitāb al-Ahkām, Bāb Mā Jā'a fi al-Rāshi wa al-Murtasyī fi al-Hukmi, no. 1337, h. 344. Ibn Mājah, Sunan, Kitāb al-Ahkām, Bāb al-Taglīz fì al-Haif wa al-Risywah, no. 2313,

22 Tirmiẓi, Sunan, Kitāb al-Ahkām, Bāb Mā Jā'a fi al-Rāsyi wa al-Murtasyī fi al-Ḥukmi, no. 1336, h. 344.

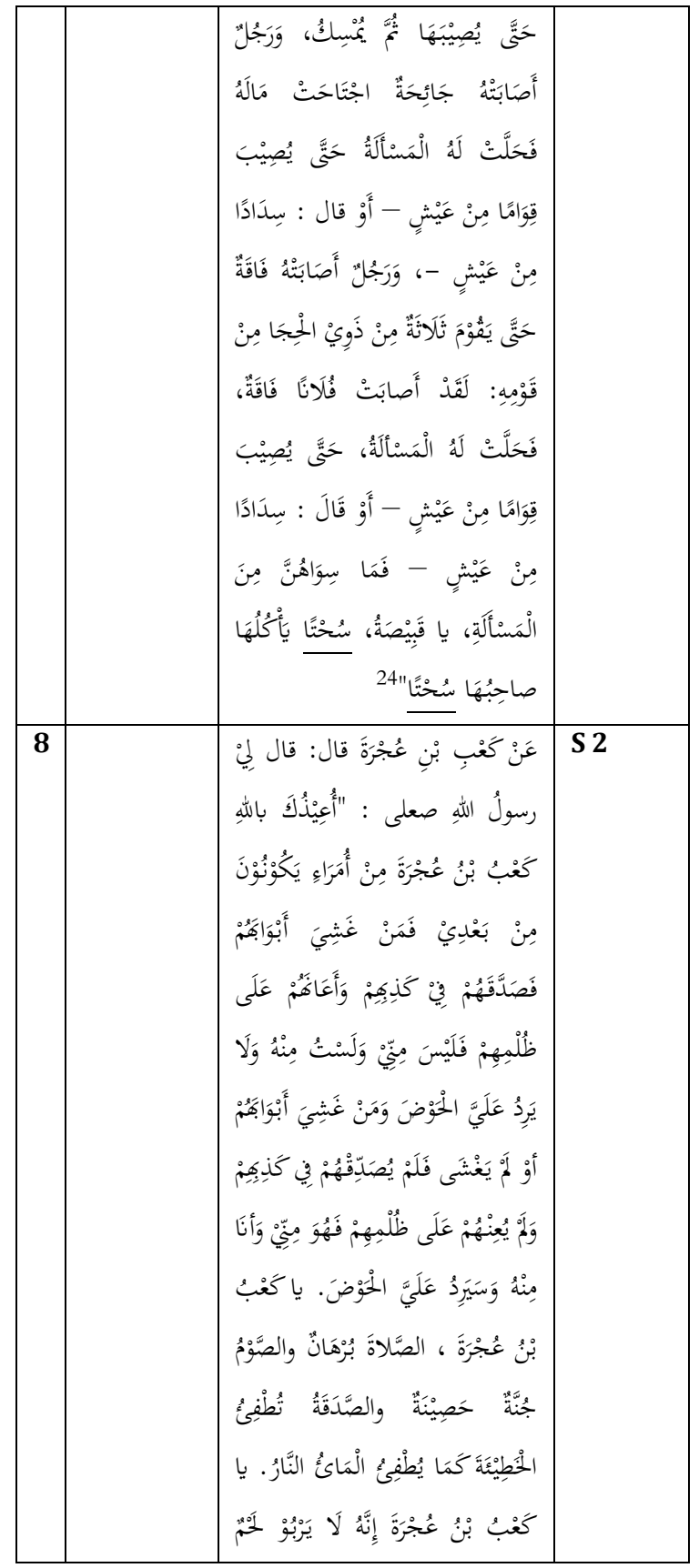

${ }^{23}$ Abū Dāwūd, Sunan, Kitāb al-Kharāj wa al-Imārah, Bāb fī Karāhiyati al-Iftirāọ fī Ākhir alZamān, no. 2959, juz 3, h. 71.

${ }^{24}$ Muslim, Șahīh, Kitāb al-Zakāh, Bāb Man Tahillu lahu al-Mas'alah, no. 1044, h. 373. Abū Dāwūd, Sunan, Kitāb al-Zakāh, Bāb Mā Tajūzu fîhi al-Mas'alah, no. 1640, juz 2, h. 40. Nasā'ī, Sunan, Kitāb al-Zakāh, Bāb al-Ṣadaqah li man Taḥammala bi Hamālatin, no 2577. Dārimī, Sunan, Kitāb al-Zakāh, Bāb Man Tahillu lahu alȘadaqah, no 1670, juz 1, h. 283-284. 


\begin{tabular}{|c|c|c|c|}
\hline & & 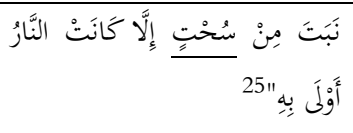 & \\
\hline 9 & $\begin{array}{l}\text { Bai'at al- } \\
\text { Imām li } \\
\text { al-Dunyāa }\end{array}$ & 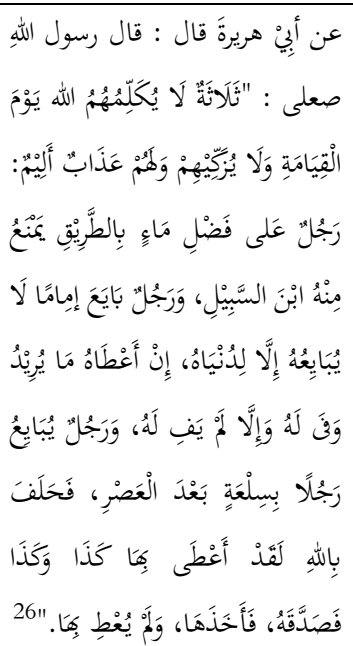 & BID 1 \\
\hline $\begin{array}{l}1 \\
0\end{array}$ & $\begin{array}{l}\text { Jaur al- } \\
\text { Qadī aw } \\
\text { al-Imām }\end{array}$ & 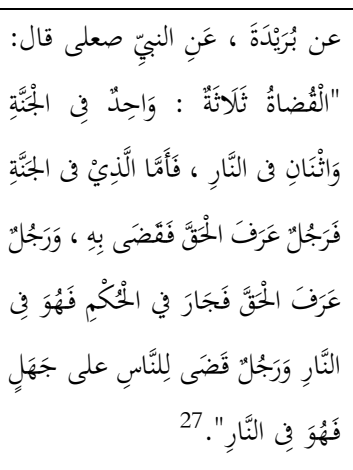 & JQI 1 \\
\hline $\begin{array}{l}1 \\
1\end{array}$ & & 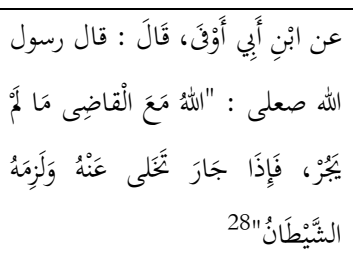 & JQI 2 \\
\hline $\begin{array}{l}1 \\
2\end{array}$ & & 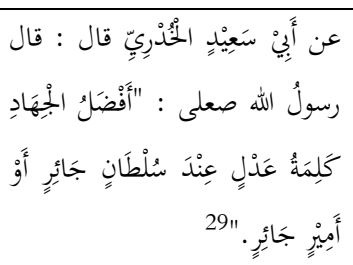 & JQI 3 \\
\hline
\end{tabular}

25 Tirmizì, Sunan, Bāb Mā Zukira fì Fadli alȘalāh, no. 614, h. 177. Aḥmad, Musnad, juz 3, h. 321 dan 399.

${ }^{26}$ Bukhārī, Sahīh, Kitāb al-Ahkām, Bāb Man Bāya'a Rajulan lā Yubāyi'uhu illā li al-Dunyā, no. 7212, h. 1306. Bukhārī, Kitāb al-Shahādāt, Bāb al-Yamīn ba'da al-'Așri, no. 2672, h. 486-487.

27 Abū Dāwūd, Sunan, Kitāb al-Aqḍiyyah, Bāb fĩ al-Qāḍī Yukhți'u, no. 3573, Juz 3, h. 288289. Ibn Mājah, Sunan, Kitāb al-Aḥkām, Bāb alHākim Yajtahidu fa Yușību al-Haq, No. 2315, h. 370.

28 Tirmīzī, Sunan, Kitāb al-Ahkām, Bāb Mā Jā'a fĩ al-Imām al-'Ādil, No. 1330, h. 343.

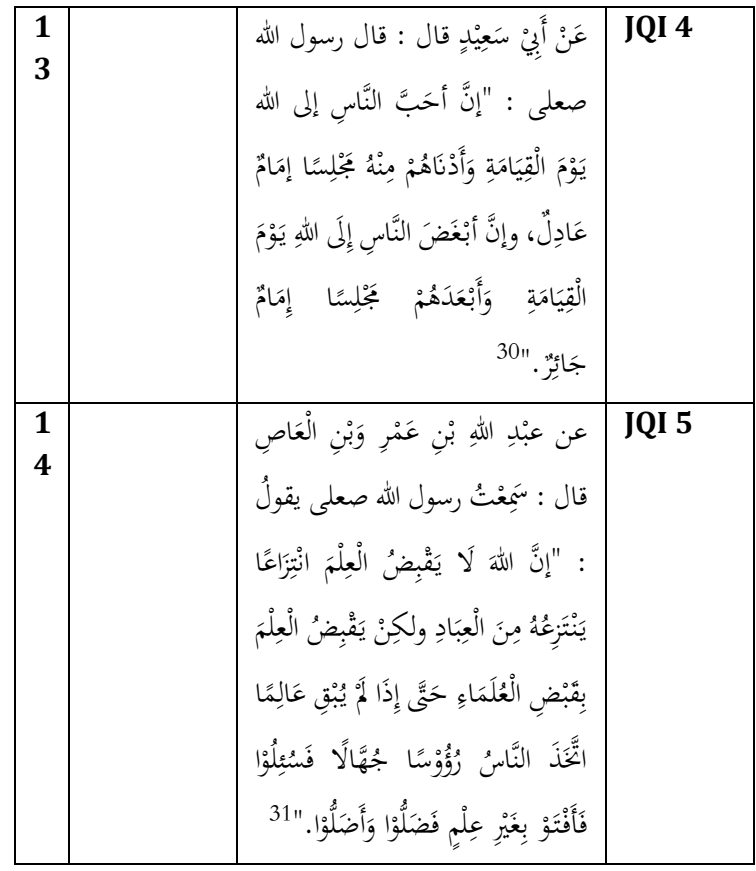

Metode Penelitian

Penelitian ini adalah penelitian kualitatif berdasarkan penguraian atau reduksi datanya. Penelitian ini juga tergolong sebagai penelitian pustaka karena objek materil dan objek formil dalam penelitian ini diambil dari literasi kepustakaan yang digunakan dalam penyusunan kerangka berpikir yang menjadi landasan sejak awal hingga

JURNAL AQLAM -- Journal of Islam and Plurality -- Volume 3, Nomor 2, Desen primer atau objek materıl penelıtıan ını adalah kitab berjudul Kutub al-Sittah.

Proses pengumpulan data yang berasal dari buku/kitab Kutub al-Sittah dilakukan dengan beberapa tahap. Pertama, menginventarisir hadithhadith yang memiliki probabilitas

29 Abū Dāwūd, Sunan, Kitāb al-Malāhīm, Bāb al-Amr wa al-Nahy, No. 4344, Juz 4, h. 109. Tirmiẓ̄, Sunan, Kitāb al-Fitan, Bāb Mā Jā'a Afḍalu al-Jihād Kalimāt Haq 'inda Sulțān Jā'ir, No. 2174, h. 524.

30 Tirmizi, Sunan, Kitāb al-Ahkām, Bāb Mā Jā'a fī al-Imām al-'Ādil, No. 1329, h. 343.

31 Bukhārī, Sahīh, Kitāb al-'Ilmi, Bāb Kaifa Yuqbaḍu al-'Ilmu, No. 100, h. 37. Muslim, Șahīḥ, Kitāb al-'Ilmi, Bāb Raf'i al-'Ilmi waQabḍihi, No. 2673, h. 1030. Tirmizi, Sunan, Abwāb al-'Ilmi, Bāb Mā Jā'a fĩ Zihābī al-'Ilmi, No. 2652, h. 625. AlManāwī, Faiḍ al-Qadīr, No. 1826, Jilid 2, h. 347. 
sebagai indikator, penjelasan, bahkan pengertian dari korupsi, kolusi, dan nepotisme. Kedua, mengklasifikasi istilah-istilah korupsi, kolusi, dan nepotisme dari hadith-hadith yang diteliti. Istilah-istilah korupsi, kolusi, dan nepotisme berupa Ghulūl, Rishwah, Suht, Bai'at al-Imām li al-Dunyā, dan Jaur al-Qadì aw al-Imām disampaikan di pendahuluan sebagai bahan dasar analisis di pembahasan selanjutnya.

Proses analisis dalam penelitian ini dilakukan dengan beberapa tahap. Pertama, menandai kata, diksi, atau redaksi yang menunjukkan pemaknaan atau pembahasa korupsi, kolusi, dan nepotisme di setiap hadith yang diteliti. Kedua, memberikan komentar terkait status dan kualitas hadith. Ketiga, mendefinisikan istilah-istilah korupsi, kolusi, dan nepotisme dalam hadith secara kebahasaan. Keempat, memberikan komentar dan penafsiran dari para muhaddith terkait maksud dari redaksi, diksi, atau kata yang terkait dengan korupsi, kolusi, dan nepotisme di setiap hadithnya. Kelima, menyampaikan kondisi korupsi, kolusi, dan nepotisme pada masa Muhammad ibn 'Abdillah SAW yang berkaitan pada setiap kasus di setiap hadithnya. Keenam, malakukan interpretasi linguistik. Ketujuh, malakukan perpaduan analisis antara interpretasi linguistik, kondisi pada masa Muhammad ibn 'Abdillah SAW melalui beragam literasi, dan keterangan dari asbāb al-Wurūd. Ketujuh, malakukan framming.

\section{Korupsi, Kolusi, dan Nepotisme dalam Istilah al-GhulūI}

32 Muslim menjelaskan dugaan kuat bahwa Ibn 'Āmir terlibat dalam kasus korupsi فمعناه إنك

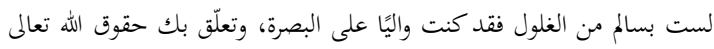

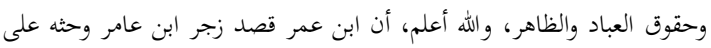

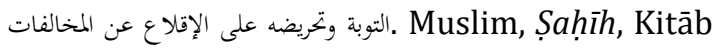
al-Ṭahārah, Bāb Wujūd al-Ṭahārah li al-Ṣalāh, no. 224, Cetakan Kedua (Kerajaan Saudi Arabia
Hadis G1 merupakan hadith yang secara terus-terang ditujukan pada tindakan korupsi. Hal ini dapat dilihat dari pernyataan وكنتَ على البصرة Umar ibn Khattāb pada Ibn 'Āmir.

Pernyataan tersebut dimaknai Muslim bahwa Ibn 'Āmir tidak mungkin mendapat perhatian dari Allah atas penyakit yang menimpanya karena disinyalir terjerat kasus keadilan sosial berupa penyimpangan hak-hak Allah, masyarakat, dan lingkungan.

Muslim juga berpendapat bahwa Umar ibn al-Khattāb bermaksud menyadarkan Ibn 'Āmir dengan mengupayakan agar bertaubat dan memperbaiki kesalahan-kesalahan yang diperbuat terkait dengan korupsi. ${ }^{32}$

Hadis G2 yang tidak memiliki kecenderungan dalam tipologi korupsi, kolusi, maupun nepotisme perlu diamati lebih jauh. Penulusuran sejarah (asbāb al-Wurūd) dan interpretasi muhaddith tidak menjelaskan secara rinci Hadis ini.

Penyatuan seluruh struktur teks Hadis diupayakan untuk memperoleh pemahaman dan maksud sehingga tidak menyisakan kabar yang sulit dipahami. Penyatuan tersebut dimaksudkan tidak hanya untuk menghilangkan kesan kontradiksi dalam Hadis semata. Sisi lain penyatuan unsur linguistik teks KORUPSI, KOLUSI DAN NEPOTIS

Haais sepenarnya memılkı maksua yang tidak jauh berbeda. ${ }^{33}$

Diksi al-Ghulūl yang berada diantara al-Kanz dan al-Dain memungkinkan memiliki makna yang dapat menjembatani kontradiksi makna diantara keduanya. Kata al-Kanz yang

Kementerian Agama Islam, Wakaf, Dakwah, dan Penerangan: Darus Salam, Muharram 1421/April 2002), 114.

33 Laila Sari Masyhur, "Studi Analitik Hadits Penyalahgunaan Fungsi Jabatan: Kasus Ibnu Lutbiah,"Jurnal Ushuluddin, Vol. XVII, No. 1 (Januari 2011): 98-114 [109]. Lihat juga Nuruddin 'Itr, Manhaj al-Naqd fí 'Ulūm al-Hadis, Cetakan Ketiga (Beirut: Dar al-Fikr, 1997), 338. 
berarti menimbun barang dan kata alDain yang berarti hutang adalah potret kontradiksi atau oposisi biner yang memungkinkan bahwa makna al-Ghulūl dalam konteks kalimat ini memiliki citra sebagai sesuatu yang dapat menjembatani kedua redaksi kontradiktif tersebut.

Hal ini memungkinkan bahwa kata al-Ghulūl memiliki makna menyuap atau menyogok; dan atau korupsi. Pemaknaan tersebut didasarkan karena al-Kanz merupakan potret ekonomi yang menunjukkan kemapanan dan alDain menunjukkan ketidakmapanan.

Pemaknaan sogok atau suap merupakan unsur terpenting dari kolusi dan nepotisme yang bernuansa untuk subjektifitas kepentingan pribadi, keluarga, kelompok penyuap atau penyogok. Hal ini menyebabkan bahwa kata al-Ghulūl pada G2 tidak hanya dimaknai sebagai korupsi, namun juga kolusi dan nepotisme.

\section{Korupsi, Kolusi, dan Nepotisme dalam Istilah Rishwah}

Hadis R1 bernuansa kolusi dan nepotisme. Abū 'Īsā menyatakan bahwa kualitas Hadis adalah hasan sahīh dan diriwayatkan oleh Abī Salamah ibn 'Abd al-Rahmān yang didapatkan dari 'Abdullah ibn 'Amr. ${ }^{34}$

Hadis ini merupakan kecaman. Kecaman ini ditujukan pada al-Rāshī dan al-Murtashī. Definisi al-Rāshī sebagai alMu'țī (المعطى) dan al-Murtashī sebagai alĀkhidh (الآخذ) oleh al-Tarmidhī dimaksud sebagai dua tindakan indisipliner dengan menggunakan cara illegal (nail bi bāțīlan) dan mengajukan

34 Abū 'Îsa Muhammad ibn 'Îsā alTarmidhī, Sunan al-Tarmidhī, Bāb Mā Jā'a fi alRāshī wa al-Murtashī fi al-Hukm, Hadis ke-1341 (Beirut: Dar al-Fikr, 2005). 408. Kualitas șahīh didasarkan pada riwayat 'Alī ibn Muhammad, lihat Abī 'Abdillāh Muhammad ibn Yazīd alQazwīnī (Ibn Mājah), Sunan, Kitāb al-Ahkām, maksud kontra produktif (tawșșul badālī zulmin). ${ }^{35}$

Redaksi al-Rāshī dan al-Murtashī yang didasarkan pada bentuk mașdar berupa rishwah yang berarti pemberian, sogokan, atau suap ini merupakan fakta sosial yang terekam dan dilembagakan oleh ucapan Muhammad ini merupakan tindakan sosial secara aktif yang melibatkan lebih dari satu orang atau pihak. Hal ini berdampak pada asosiasi rishwah dalam Hadis R1 ini tidak mungkin mengacu pada kenyataan korupsi pada masa itu.

Oposisi biner yang menghadirkan dua redaksi dalam oral Muhammad merupakan rekaman keberadaan interaksi aktif antara al-Rāshī dan alMurtashī. Hadis ini tidak menjelaskan rantai keuntungan (dalam konteks negatif-destruktif) yang dialamatkan untuk keluarga atau rekanan pelaku yang terlibat rishwah sehingga mempermudah asosiasi istilah rishwah sebagai bentuk nepotisme.

Hadis ini merupakan bentuk kecaman dan ancaman untuk tidak melakukan rishwah sehingga bagi pelaku yang melanggar ucapan Muhammad dapat dikategorikan sebagai upaya melawan hukum yang biasa disebut kolusi. Hal ini

JURNAL AQLAM -- Journal of Islam and Plurality -- Volume 3, Nomor 2, Desen cenderung bernuansa kolusı disbanding sekedar nepotisme, terlebih korupsi.

Hadith R2 bernuansa kolusi dan nepotisme. Abū 'Īsā menyatakan bahwa kualitas Hadis adalah hasan șahīh dan diriwayatkan oleh Abū Mūsā Muhammad ibn al-Muthannā yang diketahui dari Abū 'Āmir al-'Aqadiyy. ${ }^{36}$

Bāb al-Taglīz fĩ al-Haif wa al-Rishwah, no. 2313 (Riyād: Maktabatu al-Mufāriq, 1417 H.), 396.

35 Abī 'Īsā Muhammad ibn 'Īsā ibn alTarmidhī, Jāmi'u al-Tarmidhi ma'a Shamāilu alTarmidhi (TK: TP., T.Th), 212.

${ }^{36}$ Informasi lain menyatakan bahwa Hadis ini diriwayatkan oleh Ibn Abī Dhi'bin yang diketahui dari Khālid al-Hāarith ibn 'Abd al- 
Hadis yang tidak ditemukan $a s b \bar{a} b$ al-Wurūd nya ini menampilkan dua redaksi yang saling berinteraksi sehingga mendekati pada definisi nepotisme walaupun tidak dijelaskan status kekerabatan dan sosial yang terjalin antara al-Rāshī, al-Murtashī, dan pihak lain secara mendetil.

Hal inilah yang menyebabkan redaksi rishwah sebagai kata mendasar dan kata kunci dalam hadith ini cenderung mendekati nuansa dan etimologi nepotisme. ${ }^{37}$

Pelaksanaan suap dan penerimaan suap setelah ucapan Muhammad dalam R2 ini di masanya merupakan tindakan melawan hukum yang dapat dikategorikan sebagai kolusi. ${ }^{38}$

Hadis R3 mengandung unsur kolusi dan nepotisme. Hal ini didasarkan pada redaksi al-'Ațā'u yang berarti pemberian (tentu dengan konotasi negatif dalam konteks perebutan kekuasaan yang ditandai dengan redaksi 39 dan rushān yang berarti sogokan atau suap.

$\begin{array}{ccc}\text { Kasus } & \text { nepotisme } & \text { yang } \\ \text { mensyaratkan } & \text { adanya } & \text { upaya }\end{array}$
menguntungkan diri sendiri dan jalinan sosial terdekat dibuktikan dengan terciptanya budaya "memberi" untuk maksud pragmatis.

Bentuk lain dari nepotisme adalah upaya perekrutan individu tanpa

Raḥmān. Khalid mengetahuinya dari Abī Salamah yang mengetahuinya dari 'Abdillah ibn 'Amr. Abū 'İsa Muhammad ibn 'Īsā al-Tarmidhī, Sunan al-Tarmidhī, Bāb Mā Jā'a fi al-Rāshī wa alMurtashī fi al-Hukm, Hadis ke-1342 (Beirut: Dar al-Fikr, 2005). 408.

37 Undang-undang Republik Indonesia Nomor 28 Tahun 1999 tentang Penyelenggaraan Negara yang Bersih dan Bebas dari Korupsi, Kolusi, dan Nepotisme, Bab I Ketentuan Umum, Pasal 1, Ayat 3, 4, dan 5.

38 Undang-undang Republik Indonesia Nomor 28 Tahun 1999 tentang Penyelenggaraan Negara yang Bersih dan Bebas dari Korupsi, Kolusi, dan Nepotisme, Bab I Ketentuan Umum, Pasal 1, Ayat 3, 4, dan 5. mempertimbangkan peraturan atau proses uji kelayakan. Hal ini merupakan upaya inkonstitusional yang terjadi di masa Muhammad untuk mempertahankan atau untuk merebut kekuasaan sebagaimana tertulis dalam tekstualitas hadïth بلى على الملك فيما بينها

Nepotisme terjadi di tengah kondisi masyarakat suku Quraish yang saling bersaing dan bertikai untuk memperebutkan kekuasaan sehingga netralitas dan objektifitas untuk memilih pemimpin atau suatu kebijakan yang bersifat produktif, konstruktif, dan visioner diabaikan oleh upaya perekrutan jalur kekerabatan dan pertemanan dalam mengisi posisi kekuasaan dan dominasi permufakatan

KORUPSI, KOLUSI DAN NEPOTIS

uarı proses musyawaran yang teran dilakukan sebelumnya. ${ }^{41}$

Kasus kolusi yang terjadi dalam penggambaran Hadis R3 ditandai dengan redaksi العطاء atau رشا. Kedua tindakan ini menuntut adanya kerjasama secara aktif dalam rangka menyalahi ketentuan, peraturan, dan hukum.

Kedua tindakan ini berbanding sejajar dengan definisi kolusi yang berbunyı pemufakatan atau kerjasama secara melawan hukum antarPenyelenggara Negara atau antar Penyelenggara Negara dan pihak lain

39 Kata al-'Ațā'u berarti gift atau present dalam bahasa Inggris yang dapat juga berarti "pemberian" dalam bahasa Indonesia. Kata ini merupakan bentuk tunggal dari al-A'tiyyah (الأَعْعِيَّة Hehr, A Dictionary of Modern Wrtten Arabic, Ed. J. Milton Cowan, Edisi Ketiga (New York: Spoken Language Services, 1971), 622.

40 Andrew Hoctor, Nepotism \& HRM Practices - How They Affect Player Satisfaction: A Study of G.A.A Clubs (National College of Ireland, 2012), 11.

41 L. Wong dan B. Klenier, Nepotism International Journal of Productivity and Performance Management, Vol. 3, No. 34 (1994): 10-19. 
yang merugikan orang lain, masyarakat, dan atau negara. ${ }^{42}$

Hal inilah yang menyebabkan redaksi رشا atau pada Hadis R3 mewakili dua dimensi intoleraninkonsisten berupa nepotisme dan korupsi.

\section{Korupsi, Kolusi, dan Nepotisme dalam Istilah Suht}

Hadis S1 mengandung kecenderungan dan nuansa nepotisme. Hal ini didasarkan pada perbuatan meminta-minta yang dilarang kecuali tiga hal berupa beban, hutang, atau tanggungjawab (تحمُّل الحمّالة);3 bencana atau kecelakaan (جائِحَة); dan kebangkrutan atau kerugian (فاقَة).

Perbuatan meminta-minta selain ketiga pengecualian tersebut di atas dikategorikan sebagai suht yang berarti barang yang tidak terjangkau (ill-gotten property), kepemilikan ilegal (illegal possession), perdagangan yang tidak sah (unlawful trade), sesuatu yang terlarang (something forbidden). ${ }^{44}$

Redaksi Hadis S1 yang membicarakan tentang perbuatan "meminta-minta" adalah kondisi dimana salah seorang muslim mengajukan permintaan pada Muhammad. Permintaan seperti ini dapat terjalin

42 Kolusi dalam aspek perdagangan didefinisikan sebagai hubungan antara penawar (bidder) yang membatasi persaingan dan merugikan pembeli publik. 24.

43 Redaksi مَّمالة didefinisikan oleh Muslim sebagai harta yang ditanggung manusia. Hal ini dimaksudkan bahwa seseorang yang menengadahkan tangannya dalam keadaan genting kemudian pihak atau lain mengulurkan tangannya atau memberi atau membayarkan pada peminta tersebut dengan kerelaan (إصلاح) antara kedua belah pihak yang menunjukkan suatu jelas atau lugas ذات البين. Abī al-Husainī ibn al-Hajjājī ibn al-Muslim al-Qusairiyyi alNaisābūriyy, Șaḥīh Muslim, Cetakan Kedua (Kerajaan Arab Saudi: Dar al-Salām dan dengan adanya kesepakatan dan fungsi aktif dari pihak peminta dan pihak pemberi.

Tindakan yang dimaksud dengan suht seperti ini juga tidak harus menanti kesepakatan dan kerjasama pihak peminta dan pemberi karena Muslim memberi keterangan bahwa tindakan ini adalah tindakan yang dilarang atau harām. ${ }^{45}$

Tindakan seperti ini tentu berpotensi untuk tidak hanya pada dirinya sendiri, namun juga pada pihak kekerabatan dan pertemanan dalam individu sosial yang berkaitan dan dekat dengan pihak peminta atau pihak yang melakukan suht. Hal inilah yang menyebabkan bahwa Hadis S1 lebih JURNAL AQLAM -- Journal of Islam and Plurality -- Volume 3, Nomor 2, Dese korupsi maupun kolusi dalam pendekatan kebahasaan.

Hadis S2 yang berstatus hasan gharīb ini cenderung bernuansa korupsi dan nepotisme. ${ }^{46}$ Hal ini didasarkan pada beberapa peristiwa sebelum pembahasan șuht berupa para pemimpin yang intoleran dan indisipliner; pemebenaran kebohongan beserta konsekuensinya; dukungan kedzalim-an beserta konsekuensinya; perlawanan terhadap kebohongan dank e-dzalim-an beserta konsekuensinya; șalāt sebagai bukti kebenaran; puasa

Kementerian Agama Islam, Wakaf, Dakwah dan Penerangan, April 2000 M. / Muharram 1421 H.), 419,

44 Rohi Baalbaki, al-Mawrīd, Cetakan Ketujuh (Beirut: Dar al-'Ilm li al-Malāyīn, 1995), 625.

45 Abī al-Husainī ibn al-Hajjājī ibn alMuslim al-Qusairiyyi al-Naisābūriyy, Șah̄ih Muslim, Cetakan Kedua (Kerajaan Arab Saudi: Dar al-Salām dan Kementerian Agama Islam, Wakaf, Dakwah dan Penerangan, April 2000 M./Muharram 1421 H.), 420.

${ }^{46}$ Nur Achmad, Pencegahan Korupsi dalam Perspektif Hadis: Studi Hadis Korupsi dalam Kutub al-Sittah, Tesis (Jakarta: Sekolah PAscasarjana Universitas Islam Syarif Hidayatullah, 2007), 119. 
sebagai pelindung kebenaran; dan sedekah sebagai penghapus kesalahan.

Peristiwa-peristiwa tersebut diakhiri ungkapan bahwa anggota tubuh biologis yang eksis didasarkan pada indikasi suht mendapat perhatian berupa neraka sebagai responnya.

Hal ini dapat dirujuk pada peristiwa-peristiwa yang mengawali sebelumnya bahwa Muhammad telah meramalkan suatu masa yang sulit untuk membedakan kehalalan dan keharaman sesuatu yang dikonsumsi.

Hal ini didasarkan pada kondisi pemerintahan di suatu daerah (negara) yang inkonsisten dan inkonstitusional. Solusi yang bersifat preventif dari Muhammad adalah salat, puasa, dan zakat untuk mengontrolkedisiplinan mental, pikiran, dan tubuh dari makanan dan minuman yang dikonsumsi.

Suatu yang telah dikonsumisi dan menjadi daging dapat dikategorikan sebagai makanan dan minuman yang memungkinkan untuk didapat dari hasil mengambil secara illegal berupa korupsi; dan persekongkolan untuk memperoleh suatu tujuan yang dapat dinikmati oleh diri pribadi dan rantai sosial terdekat berupa nepotisme.

Hadis S2 ini tidak dapat dikategorikan sebagai kolusi karena substansi pemahaman dan definisi dari kolusi adalah permufakatan sosial dalam melawan hokum sebagai tindakan utama.

\section{Korupsi, Kolusi, dan Nepotisme dalam Istilah Bai'at al-Imām li al- Dunyā}

Hadis BID 1 merupakan gambaran kondisi kolusi. Hadis dengan kualitas

47 Ibn Mājah, Sunan, Kitāb Tijārāt, Bāb Mā Jā'a fĩ al-Karāhiyati al-Aimān fĩ al-Syarā' wa alBai', No. 2207, Cetakan Pertama (Riyad: Maktabatu al-Ma'ārif, 1417 H.), 379-380.

${ }^{48}$ Bukhārī, Șahīh, Kitāb al-Ahkām, Bāb Man Bāya'a Rajulan Lā Yubāyi'uhu illā li alDunyā, No. 7212 (), 1513. sahīh ini ${ }^{47}$ menampilkan tiga peristiwa yang sosial yang berkaitan sebagai bentuk respon terhadap fakta kemanusiaan masa Muhammad berupa apresiasi terhadap backpacker (Ibn alSabīl), persekongkolan dan consensus dalam pengangkatan seseorang untuk menjadi pemimpin (Bai'atu al-Imām), dan duata dalam berniaga atau berdagang. ${ }^{48}$

Peristiwa pertama merupakan manajemen sosial. Peristiwa kedua merupakan etika musyawarah-mufakat, etika kepemimpinan, tata kelola pemerintahan. Peristiwa ketiga merupakan etika bisnis.

Ketiganya merupakan suatu interaksi kemanusiaan yang berkonotasi negatif. Ketiganya juga menyuguhkan perhatian pada peristiwa kedua berupa Bai'at al-Imām li al-Dunyā.

Redaksi Bai'at al-Imām li alDunyā lebih mendekati pada konteks dan definisi kolusi yang menekankan adanya pemufakatan jahat untuk

KORUPSI, KOLUSI DAN NEPOTISN

pemimpın untuк кepentingan sesaat (II al-Dunyā).

Pengangkatan seseorang pemimpin tidak dapat dilandasi dari kepentingan kelompok tertentu. Hal ini di luar etika pemilihan pemimpin yang sewajarnya dipilih berdasarkan status kredibilitas dan otentisitas model peran etis calon pemimpin; kemampuan untuk peka terhadap isu terbaru yang penting; keberadaan iklim pemilihan yang mempertimbangkan sisi manajemen pribadi dan manajemen sosial dari calon pemimpin itu sendiri. ${ }^{49}$

Konsep penting kedua yang lahir dari definisi korupsi adalah potensi atau

49 Cristopher M. Barnes dan Lieutenant Colonel Joseph, What Does Contemporary Science Say about Ethical Leadership? (The Army Ethic of Military Review, 2010), 90-91. 
penemuan kerugian bagi orang lain. Redaksi Bai'at al-Imām li al-Dunyā dalam Hadis BID 1 dipastikan memiliki potensi yang merugikan bagi calon pemimpin lain secara langsung dan bagi rakyat atau pihak yang akan dipimpin secara tidak langsung. Hal ini terjadi karena adanya upaya untuk membungkam karakter pemimpin ideal. ${ }^{50}$

Hal inilah yang menyebabkan istilah Bai'at al-Imām li al-Dunyā dalam Hadis BID 1 tidak tepat disandingkan pada kondisi nepotisme yang menitik beratkan pada upaya memberi keuntungan pada diri sendiri, keluarga, sahabat, kelompok, dan pihak tertentu semata tanpa berupaya mengakomodasi banyak pihak secara komprehensif dan adil.

\section{Korupsi, Kolusi, dan Nepotisme dalam Istilah Jaur al-Qadī aw al-Imām}

Hadis JQI 1 menyoroti fenomena perlawanan terhadap hukum dan kebodohan (keteledoran atau kelalaian) yang dilakukan oleh hakim sebagai bentuk kolusi dan nepotisme. Ibn Mājah menyatakan bahwa kualitas Hadis ini adalah sahīh. ${ }^{51}$

Hakim yang memutuskan suatu perkara tanpa dilandasi peraturan dan hukum yang berlaku merupakan upaya

50 Karakter pemimpin ideal yang tidak merugikan orang lain dan tidak didasarkan pada kepentingan sesaat (li al-Dunyā) dapat dilihat dari parameter nilai, sikap, kepercayaan, perilaku, kebiasaan dan praktik dan sampai batas tertentu tergantung pada budaya organisasi, profesional atau institusional. Katarina Katja Mihelic, Bogran Lipicnik, dan Metka Tekavcic, "Ethical Leadership," International Journal of Management \& Information Systems, Vol. 14, No. 5 (Fourth Quarter 2010): 31-42 [32].

51 Abī 'Abdillāh Muhammad ibn Yazīd alQazwīnī (Ibn Mājah), Sunan Ibn Mājah, Kitāb alAḥkām, Bāb al-Ḥākimu Yajtahidu Fayuṣību alHaq, Hadis Ke 2315 (Riyad: Maktabatu alMa'ārif, 1417 H.), 396. perlawanan hukum secara sengaja dan berdampak pada kerugian yang dialami orang lain sebagaimana definisi kolusi yang hadir dari UU RI Tahun 1999.52

Pemahaman mendasar terkait kolusi adalah "kerjasama" yang memiliki konotasi yang negatif. ${ }^{53}$ Hal inilah yang menyebabkan bahwa perisitiwa perlawanan hukum dengan istilah Jaur al-Qāọī aw al-Imām pada Hadis JQI 1 merupakan gambaran kolusi yang terjadi secara nyata pada masa Muhammad.

Kolusi yang dilakukan oleh aparat penegakan hukum dapat berdampak

JURNAL AQLAM -- Journal of Islam and Plurality -- Volume 3, Nomor 2, Desen layanan publik secara kualitas dan jangkauan. 54

Peristiwa kelalaian atau keteledoran seorang hakim dalam memutuskan suatu perkara merupakan tindakan ketidakadilan karena jabatan atau posisi tersebut menuntut adanya kemampuan dan kecakapan yang disyaratkan sebagai bentuk menjunjung objektifitas dalam rangka menyelenggarakan salah satu penerjemahan keadilan. Salah satu unsur yang perlu dipahami dari tindakan kelalaian adalah ketidaktahuan. ${ }^{55}$

Seorang hakim yang tidak tahu dalam proses dan regulasi penyelesaian

52 Undang-undang Republik Indonesia Nomor 28 Tahun 1999 tentang Penyelenggaraan Negara yang Bersih dan Bebas dari Korupsi, Kolusi, dan Nepotisme, Bab I Ketentuan Umum, Pasal 1, Ayat 3, 4, dan 5.

53 Patrick Andreoli-Versbach dan FensUwe Franck, "Econometric Evidence to Target Tacit Collusion in Oligopolistic Markets,"Journal of Competition Law \& Economics, Vol 11, No. 2 (July 2015): 463-492 [464].

54 Global Forum on Competition, Policy Roundtables: Collusion and Corruption in Public Procurement (Organisation for Economic Cooperation and Development, 2010), 10.

${ }^{55}$ Mark Spranca, Elisa Minsk, dan Jonathan Baron, Omission and Commision in Judgment and Choice, Ed. Jon Haidt (University of Pennsylvania, Augst 2003): [2]. 
masalah merupakan bentuk ketidakprofesionalan seseorang dalam berkarir. Hal ini dapat dipahami sebagai bentuk kolusi karena dianggap sebagai upaya melawan hukum yang berlaku; atau sebagai bentuk nepotisme karena ketidakkompetenan seorang hakim yang perlu dipertanyakan narasi sejarah perekrutan hakim tersebut.

Sejarah perekrutan hakim yang tidak kompeten tentu memunculkan asumsi adanya nepotisme atau perekrutan yang didasarkan pada jalur kekerabatan dan bukan berdasarkan proses kompetisi yang objektif, transparan, dan dapat dipertanggungjawabkan.

Redaksi Jaur al-Qāḍī aw al-Imām yang dilahirkan dari Hadis JQI 1 dengan peristiwa kesalahan putusan oleh hakim yang berdasarkan ketidakkompetenan atau kebodohannya ini dapat diasosiasikan sebagai bentuk lain dari nepotisme yang dilandasi subyektifitas asumsi dan ramalan Muhammad akan adanya narasi genetik proses perekrutan hakim yang bernuansa nepotisme.

Hadis JQI 2 memotret penyikapan spiritual dengan etika profesi yang menimbulkan dua kecondongan penafsiran berupa korupsi, kolusi, dan nepotisme. Hadis ini memiliki kualitas hasan gharīb menurut Tirmizi atau șaḥih menurut al-Manāwi. ${ }^{56}$

Seorang hakim yang bertindak adil tanpa memihak pada subyektivitas tertentu dan tidak melanggar aturan hukum yang berlaku merupakan gambaran etika profesi yang didukung oleh pesan agama sebagaimana redaksi

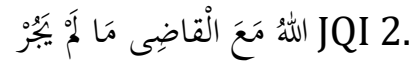

Redaksi 수요 yang berarti menyimpang adalah tindakan negatif

56 Nur Achmad, Pencegahan Korupsi Perspektif Hadis: Studi Hadis Korupsi dalam Kutub al-Sittah, Tesis (Jakarta: Sekolah yang tidak spesifik merujuk pada perbuatan tertentu, namun dapat diklasifikasikan berdasarkan kasus yang memungkinkan terjadi pada seorang hakim.

Redaksi Jaur al-Qāḍī aw al-Imām sebagai istilah yang dimunculkan dari upaya penyimpangan atau ketidakadilan (yang dibuktikan dengan redaksi seorang hakim dari Hadis ini dapat dikategorikan ke dalam tiga persoalan berupa korupsi, kolusi, dan nepotisme.

Ketidakadilan yang dilakukan seorang hakim dalam menjalankan profesinya yang melibatkan hubungan kerjasama untuk melawan hukum yang berlaku merupakan potret kolusi.

Ketidakadilan dalam mereduksi atau mengeliminasi pertimbangan yang dijadikan dasar untuk memutuskan suatu perkara merupakan upaya korupsi dari seorang hakim.

Upaya untuk memenangkan atau membijaki suatu permasalahan yang melibatkan rekan atau keluarga dari hakim merupakan tindakan subyektif untuk menguntungkan jalinan sosial terdekat secara sepihak. Hal ini merupakan upaya nepotisme.

Hadis JQI 3 dapat dikategorikan sebagai Hadis yang memiliki kecenderungan dan nuansa pada korupsi, kolusi, dan nepotisme.

KORUPSI, KOLUSI DAN NEPOTIS

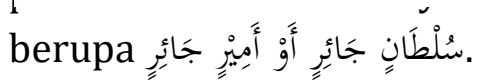

Redaksi ini didasarkan pada ketidakadilan yang perlu dituntut oleh siapapun. Penyimpangan yang dilakukan oleh seorang pemimpin dapat didasarkan pada dua hal yaitu kesengajaan dan politis; dan kesewenang-wenangan. ${ }^{57}$

Pascasarjana Universitas Islam Negeri Syarif Hidayatullah, 2007), 121.

57 Human Right Watch, They Want Us

Exterminated: Murder, Torture, Sexual 
Unsur kesengajaan yang dilakukan pemimpin yang berbuat tidak adil dapat dikategorikan sebagai gambaran korupsi yang terjadi pada masa Muhammad dalam hal administrasi, birokrasi, dan keuangan.

Unsur politis yang dilakukan pemimpin dalam pemimpin untuk tidak mendistribusikan keadilan secara merata dan terkesan subyektif dapat dikategorikan sebagai upaya nepotisme karena hal ini dilakukan untuk keuntungan dan kepentingan yang dapat dinikmati oleh pihak tertentu semata tanpa mempertimbangkan asas akomodasi dan kemerataan.

Unsur kesewenang-wenangan yang dilakukan seorang pemimpin yang tidak adil di masa nabi dapat pahami dengan mempertimbangkan kemungkinan keberadaan upaya pemanfaatan jabatan dan pangkat tertentu untuk berkomunikasi dan atau bekerjasama antara sesama elemen pemerintahan atau di luar elemen pemerintahan untuk untuk melemahkan atau merekayasa suatu aturan atau produk hukum yang telah ada dan berlaku.

Hal inilah yang menyebabkan pemimpin yang menyeleweng dapat dikategorikan sebagai bentuk kolusi. Pembenaran agama dengan menginstruksikan untuk memberi peringatan pada pemimpin yang melanggar atau menyeleweng sebagai bentuk kebebasan berpendapat yang dibuktikan dengan redaksi أَفضضَلُ الِْجَهادِ كَلِمَةُ

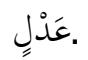

Perhatian agama terhadap indikasi kontra komitmen pada diri pemimpin juga dapat diasumsikan

Orientation and Gender in Iraq (New York: 2009), 35.

58 Human Right Watch, They Want US Exterminated: Murder, Torture, Sexual Orientation and Gender in Iraq (New York: 2009), 35. sebagai bentuk hilangnya cita-cita moral yang disebabkan oleh politik, kepentingan pribadi, dan kekuasaan. ${ }^{58}$

Hadis JQI 4 menunjukkan inkonsistensi seorang pemimpin yag digambarkan dalam redaksi جام dengan definisi "pemimpin yang menyimpang" menyisakan penalaran dan penafsiran yang beragam. Keberagaman pemahaman terkait "menyimpang" dapat dikategorikan salah satu dari atau keseluruhan dari korupsi, kolusi, dan nepotisme.

Indikasi yang muncul untuk memahami redaksi جائر (jāir) adalah dengan merujuk pada redaksi sebelumnya yang berbunyi عادل ('ādil).

Hal ini menyebabkan definisi jāir sebagai antonim dari 'âdil. Ketidakadilan dalam banyak kasus dapat dipahami sebagai bentuk pelanggaran yang tidak terbatas pada korupsi, kolusi, dan nepotisme.

HadisJQI 5 merupakan potret kolusi yang kerap terjadi dalam ranah akademik. Konspirasi dalam mengangkat pemimpin yang tidak memiliki kompetensi akademik yang memadai dalam bidang dan institusi

JURNAL AQLAM -- Journal of Islam and Plurality -- Volume 3, Nomor 2, Deser

. 59

Refleksi hadìth ini menyarankan untuk tidak memilih rektor, kepala sekolah, kyai, kepala jurusan, guru, dan sebagainya tanpa dilandasi bekal keilmuan yang mumpuni secara implisit. Sejarah kemunculan hadīth ini diawali dari konteks upaya antisipasi nabi Muhammad dalam menginstruksikan pengikutnya untuk belajar dari sumber terupdate.

59 Konteks akademik dapat dilihat dari redaksi العلم (dan beragam derivasinya), رؤوسا, dan جهالا. 
Ke-update-an suatu sumber keilmuan dalam disiplin manajemen sosial dan konflik (berupa al-Qur'ān) yang sering dikutip Nabi merupakan suatu rujukan yang lebih relevan dan lebih komprehensif dibanding rujukan yang berasal dari mușhaf yang dipercaya pengikut dari komunitas Yahudi maupun Nașrani. 60

\section{Penutup}

Penelitian ini menunjukkan bahwa empat belas hadis yang tertera sebelumnya dengan istilah khusus dari masing-masing hadis tersebut tidak dapat diasosiasikan ke dalam salah satu dari tindakan intoleran-inkonsisten berupa korupsi, kolusi, atau nepotisme semata.

Kemungkinan istilah khusus yang hadir setiap hadis pun dapat diasosiasikan pada korupsi, kolusi, dan nepotisme secara sekaligus. Hal ini juga berbanding lurus dengan upaya melihat nuansa dan kadar korupsi, kolusi, dan nepotisme di masa Muhammad yang ditentukan dari asosiasi setiap istilah yang hadir dari setiap hadìth.

\section{DAFTAR PUSTAKA}

Abū Dāwūd, Sunan.

Achmad, Nur. Pencegahan Korupsi dalam Perspektif Hadith: Studi Hadith Korupsi dalam Kutub al-Sittah, Tesis Jakarta: Sekolah

\footnotetext{
${ }^{60}$ Asbāb al-Nuzūl Hadis ini adalah اخرجه الامام

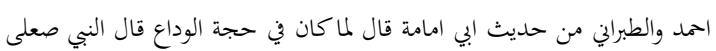

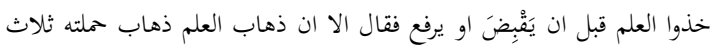

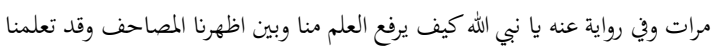

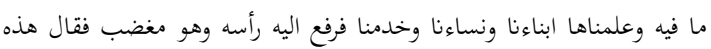
اليهود والنصارى بين اظهرهم المصاحف لم يتعلموا منها فيما جاءهم انبياءهم
}

PAscasarjana Universitas Islam Syarif Hidayatullah, 2007).

al-Naisābūriyy, Abī al-Ḥusainī ibn alḤajjājī ibn al-Muslim al-Qusairiyyi. Sahīh Muslim, Cetakan Kedua (Kerajaan Arab Saudi: Dar alSalām dan Kementerian Agama Islam, Wakaf, Dakwah dan Penerangan, April 2000 M. / Muharram 1421 H.).

al-Qazwīnī, Abī 'Abdillāh Muḥammad ibn Yazīd (Ibn Mājah), Sunan Ibn Mājah (Riyad: Maktabatu alMa'ārif, 1417 H.).

Al-Sayyid al-Sharīf al-'Allāmah alMuhaddith al-Sayyid Ibrāhīm ibn al-Sayyid Muhammad ibn alSayyid Kamāluddin Naqīb Mișr ibn Hamzah al-Husaini al-Hanafi alDamshiqi, Kitāb al-Bayānn wa alTa'rīf fï Asbāb Wurūd al-Hadìth alSharīf (T.K.: al-Bahā' Tijāh Dār alHukūmah, 1329).

Andreoli-Versbach, Patrick., dan Franck, Fens-Uwe (July 2015). "Econometric Evidence to Target Tacit Collusion in Oligopolistic

KORUPSI, KOLUSI DAN NEPOTIS

Law \& economics, vol 11 , INo. $L$ : 463-492.

Anwar, Syamsul. Fikih Antikorupsi: Perspektif Ulama Muhammadiyah Majelis Tarjih dan Tajdid PP. Muhammadiyah (Jakarta: Pusat Studi Agama dan Peradaban, 2006).

Baalbaki, Rohi. al-Mawrīd, Cetakan Ketujuh (Beirut: Dar al-'Ilm li alMalāyīn, 1995).

Barnes, Cristopher M., dan Lieutenant Colonel Joseph, What Does Contemporary Science Say about

Al-Sayyid al-Sharīf al-'Allāmah alMuhaddith al-Sayyid Ibrāhīm ibn al-Sayyid Muhammad ibn al-Sayyid Kamāluddin Naqīb Miṣr ibn Hamzah al-Husaini al-Ḥanafi alDamshiqi, Kitāb al-Bayān wa al-Ta'rīf fì Asbāb Wurūd al-Hadis al-Sharīf (T.K.: al-Bahā' Tijāh Dār al-Ḥukūmah, 1329), 187. 
Ethical Leadership? (The Army

Ethic of Military Review, 2010)

Begovic, Boris. Corruption: Concepts,

Types, Causes, and Consequences

(Center for International Private

Enterprise Economic Reform

Feature Service, 2005).

Bukhārī, Kitāb al-Shahādāt, Bāb alYamīn ba'da al-'Așri, no. 2672, h. 486-487.

Global Forum on Competition, Policy Roundtables: Collusion and Corruption in Public Procurement (Organisation for Economic Cooperation and Development, 2010).

Haller, Dieter., dan Cris Shore (Ed), Corruption: Anthropological Perspective (London: Pluto Press, 2005).

Hoctor, Andrew. Nepotism \& HRM Practices - How They Affect Player Satisfaction: A Study of G.A.A Clubs (National College of Ireland, 2012).

Human Right Watch, They Want Us Exterminated: Murder, Torture, Sexual Orientation and Gender in Iraq (New York: 2009).

Luhuringbudi, Teguh. Analisa Pengaruh al-Qawāid al-Ușūliyyah dan alFiqhiyyah terhadap Perbedaan Pendapat dalam Fiqih: Kasus Hukuman untuk Tindak Pidana Korupsi, Makalah Matakuliah Islamic Law (Jakarta: Sekolah Pascasarjana Universitas Islam Negeri Syarif Hidayatullah, 2016).

Masyhur, Laila Sari (Januari 2011). "Studi Analitik Hadits Penyalahgunaan Fungsi Jabatan: Kasus Ibnu Lutbiah,"Jurnal Ushuluddin, Vol. XVII, No. 1: 98114.

Mihelic, Katarina Katja., Lipicnik, Bogran., dan Tekavcic, Metka (Fourth Quarter 2010). "Ethical Leadership," International Journal of Management \& Information

Systems, Vol. 14, No. 5: 31-42.

Muhạmmad Nāṣir al-Dīn ibn al-Hāj Nūh al-Albāni, Al-Shaikh. Sahīh alTarghīb wa al-Tarhīb, Juz 2: 30.

Nasā'̄, Sunan, Kitāb al-Ṭahārah, Bāb Farḍ al-Wuḍū', no 139, h. 31.

Penjelasan atas Undang-undang Republik Indonesia Nomor 20 Tahun 2001 tentang Perubahan atas Undang-undang Nomor 31 Tahun 1999 tentang Pemberantasan Tindak Pidana Korupsi, Pasal 5 Ayat 2.

Shuabi, Azmi. Elements of Corruption in th eMiddle East and North Africa: The Palestinian Case, disampaikan pada 9th International AntiCorruption Conference (IACC), 1015 October, 1999, Durban, South Africa.

Spranca, Mark., Minsk, Elisa., dan Baron, Jonathan. Omission and Commision in Judgment and Choice, Ed. Jon Haidt (University of Pennsylvania, Augst 2003).

Sundell, Anders. Nepotism and Meritocracy, QoG Working Paper Series (Gothenburg: The Quality of Government Institute, 2014).

The OECD Global Forum on Competition, Collusion and Corruption in Public Procurement 2010.

Tirmiẓ̂̀, Sunan, Kitāb al-Ṭahārah, Bāb Mā Jā'a Lā Tuqbalu al-Ṣalāt bi Gairi Tahūr, no. 1, h. 9.

Treisman, Daniel (2000). "The Causes of

JURNAL AQLAM -- Journal of Islam and Plurality -- Volume 3, Nomor 2, Dese Study," Journal of Public Economics, 76: 399-457.

Undang-undang Republik Indonesia Nomor 28 Tahun 1999 tentang Penyelenggaraan Negara yang Bersih dan Bebas dari Korupsi, Kolusi, dan Nepotisme, Bab I Ketentuan Umum, Pasal 1, Ayat 3, 4, dan 5.

Undang-undang Republik Indonesia Nomor 46 Tahun 2009 tentang 
Pengadilan Tindak Pidana

Korupsi, Bab III (Kewenangan),

Pasal 6, Butir C.

Wehr, Hans. A Dictionary of Modern

Wrtten Arabic, Ed. J. Milton Cowan, Edisi Ketiga (New York: Spoken Language Services, 1971).

Wong, L., dan Klenier, B. (1994). Nepotism International Journal of Productivity and Performance Management, Vol. 3, No. 34: 10-19. 